\title{
B Cells and Autoantibodies in AIRE Deficiency
}

\author{
Anette S. B. Wolff 1,2,3, Sarah Braun 1,2,4, Eystein S. Husebye 1,2,3 and Bergithe E. Oftedal 1,2,3,* \\ 1 Department of Medicine, Haukeland University Hospital, 5021 Bergen, Norway; \\ anette.boe@uib.no (A.S.B.W.); sarah_braun95@gmx.de (S.B.); Eystein.husebye@uib.no (E.S.H.) \\ 2 Department of Clinical Science, University of Bergen, 5021 Bergen, Norway \\ 3 KG Jebsen Center for Autoimmune Disorders, University of Bergen, 5021 Bergen, Norway \\ 4 Institute of Pharmacy and Molecular Biotechnology, Ruprecht-Karls University, 69120 Heidelberg, Germany \\ * Correspondence: bergithe.oftedal@uib.no
}

check for

updates

Citation: Wolff, A.S.B.; Braun, S.; Husebye, E.S.; Oftedal, B.E. B Cells and Autoantibodies in AIRE Deficiency. Biomedicines 2021, 9, 1274. https://doi.org/10.3390/

biomedicines 9091274

Academic Editor: Amedeo Amedei

Received: 30 August 2021

Accepted: 17 September 2021

Published: 21 September 2021

Publisher's Note: MDPI stays neutral with regard to jurisdictional claims in published maps and institutional affiliations.

Copyright: (c) 2021 by the authors. Licensee MDPI, Basel, Switzerland. This article is an open access article distributed under the terms and conditions of the Creative Commons Attribution (CC BY) license (https:// creativecommons.org/licenses/by/ $4.0 /)$.

\begin{abstract}
Autoimmune polyendocrine syndrome type 1 (APS-1) is a rare but severe monogenetic autoimmune endocrine disease caused by failure of the Autoimmune Regulator (AIRE). AIRE regulates the negative selection of $T$ cells in the thymus, and the main pathogenic mechanisms are believed to be T cell-mediated, but little is known about the role of B cells. Here, we give an overview of the role of B cells in thymic and peripheral tolerance in APS-1 patients and different AIRE-deficient mouse models. We also look closely into which autoantibodies have been described for this disorder, and their implications. Based on what is known about B cell therapy in other autoimmune disorders, we outline the potential of B cell therapies in APS-1 and highlight the unresolved research questions to be answered.
\end{abstract}

Keywords: autoimmune polyendocrine syndrome type 1 (APS-1); autoantibodies; B-cells; B-cell dependent therapy; mouse models of Aire deficiency

\section{Introduction}

Autoimmune polyendocrine syndrome type 1 (APS-1), also known as autoimmune polyendocrinopathy-candidiasis-ectodermal dystrophy (APECED), is a monogenetic autoimmune disease with an estimated prevalence of 1:100,000 caused by mutations in the autoimmune regulator (AIRE) gene [1-5]. Patients usually develop autoimmune manifestations in multiple organs leading to functional impairment, especially of various endocrine glands. APS-1 is diagnosed by the presence of two out of three major clinical components of hypoparathyroidism, chronic mucocutaneous candidiasis (CMC), and primary adrenocortical insufficiency or Addison's disease. Besides these, multiple other manifestations occur, like primary ovarian insufficiency (POI), autoimmune thyroid disease, type 1 diabetes (T1D), autoimmune gastritis, keratitis, vitiligo, alopecia and enamel hypoplasia are common [1,6]. Alternatively, finding AIRE mutations and specific autoantibodies can be used diagnostically and enable early diagnosis before the main components develop [2,7].

The disease-causing mutations in AIRE are typically inherited in an autosomal recessive manner [8,9], although several heterozygous missense mutations have also been found with a dominant-negative inheritance pattern $[10,11]$. Overall, more than 130 mutations in AIRE have been identified (Human Gene Mutation Database, www.hgmd.cf.ac.uk, accessed on the 10 of May 2021), many of which cluster in key domains of the AIRE protein $[2,8,12-16]$. AIRE is mainly expressed in a subset of thymic medullary epithelial cells (mTECs), regulating the expression of $20 \%$ of the 20,000 unique tissue-restricted antigens (TRAs) to be presented to the developing T cells during negative selection [17-21]. This transcription factor contributes to the development of thymic Foxp3+ CD4+ regulatory $\mathrm{T}$ cells (Tregs) and is crucial for their ability to re-circulate back to the thymus [22-24]. In addition, AIRE is necessary for the generation of Tregs ex-thymus [25]. Indeed, APS-1 patients have decreased numbers of Tregs with a modified TCR repertoire compared to healthy individuals, reflecting the abnormal selection of T cells in the thymus [26,27]. 
Although the pathogenic mechanisms in APS-1 are T cell-mediated, the B cells are important antigen-presenting cells (APCs) that rely on T cell activation for the production of antibodies. They are found in the thymus and are also reported to have some AIRE expression themselves [28-30]. We will here look closer into what is known about the B cells in APS-1 patients and AIRE-deficient mouse models, summarize the status quo and the outstanding research questions, and highlight the therapeutic strategies involving $B$ cells in APS-1.

\section{B Cell's Contribution to APS-1 and Aire Deficiency}

Even though the loss of negative selection of T cells in the thymus also affects B cells, both in the thymus and beyond [31-33], the role of B cells and their autoantibodies in the pathogenesis of APS-1, as well as their therapeutic potential, is still incompletely known. However, exemplified by B cell depleting therapies, the role of B cells in APS-1 is likely to be more pronounced than previously assumed. One study revealed that treatment with Rituximab, a monoclonal antibody targeting CD20 and leading to B cell depletion, caused a significant reduction of inflammation, infiltration, and tissue destruction in Aire knockout mice [34]. In a study by Popler and co-workers, an APS-1 patient with severe pulmonary disease was treated with Rituximab after the failure of several other immunomodulating therapy approaches, whereupon lung function improved [35]. One could speculate if this effect is tissue-dependent and rely on the observed B cell expansion in the airway mucosal tissue upon antigen exposure [36]. If this also indicates that B cells and T cells contribute differentially to the different disease components remains to be answered. Several human studies have demonstrated recovery of APS-1-related disease components through B cell depletion by Rituximab. This includes studies on patients with isolated autoimmune Addison's disease where depletion of B cells alone or in combination with depot tetracosactide led to an increase of cortisol and aldosterone levels in a subgroup of participants $[37,38]$.

The autoantibodies produced by B cells are unlikely to be directly pathogenic; rather, they serve a mediating role in the context of an infectious milieu. This is underpinned by experiments showing that sera from AIRE-deficient mice cannot transfer autoimmunity [39]. The autoantibodies are however excellent diagnostic markers, as will be discussed later.

\section{Thymic B Cells and Their Interaction with Developing T Cells}

The B cell antigen receptor (BCR) has two roles in B cell activation; first as a binder of antigen that transmits signals directly to the cell's interior, and secondly by internalizing the antigen for degradation and subsequent presentation on the B cell surface as peptides bound to MHC class II molecules MHC-II. Antigen-specific helper T cells recognize the peptide:MHC-II complex and produce cytokines that cause the B cell to proliferate and its progeny to differentiate into antibody-secreting cells. Somatic hypermutation and switching to certain immunoglobulin isotypes depend on the interaction of antigen-stimulated B cells with helper T cells and other cells in the peripheral lymphoid organs [40]. There is a bidirectional relationship between $B$ and $T$ cells and a requirement for sequential input from both cell types to generate a successful overall outcome. It is suggested that the beneficial effect of B cell depletion in autoimmune settings could be explained by harnessing unfavorable T cell activation [41].

In the thymus, tissue-resident B cells are found at a frequency of $0.1-1 \%$ [42-46], likely reflecting the homing of peripheral B cells and their potential as APCs. In murine model systems, the thymic B cells have been found to be potent APCs able to present TRAs induced by Aire expression. Although dendritic cells (DCs) and mTECs are the major acting APCs, recent data argue that B cells have a specific role in this process, as mice lacking either B cells, DCs or had depressed MHC-II expression have an equal CD4+ single positive compartment, i.e., they are equally pivotal for intra-thymic antigen presentation [29,47]. B cells also modulate the production and maintenance of thymic Tregs $[48,49]$. Of interest, B cells within the thymus can expand and undergo class switching, thereby directly influence 
CD4 T cell tolerance. In human thymi, B cells are found in the medulla and throughout the cortex and include all developmental stages with an overweight of mature naïve $B$ cells [28]. They have been shown to express AIRE, and the expression level declines with increasing age $[28,50]$.

\section{Loss of Aire and the Consequences for B Cells Ex-Thymus}

$B$ cells have their own tolerance mechanisms which are mainly achieved within the bone marrow by clonal deletion of autoreactive cells and receptor editing to become functional receptors and to maximize recognition towards their cognate antigen [51]. The immature B cells migrate to secondary lymphoid organs where they further develop to mature B cells expressing IgM and IgD. B cells that bind their antigens and get proper T cell help in concert with CD40-CD40L binding will proliferate and differentiate into memory $B$ cells or plasma cells that secrete antibodies [52]. Antibodies produced by plasma cells have three major roles in the host defense: neutralization of pathogens, opsonization for phagocytosis, and complement activation. In peripheral tolerance, anergy is induced in the remaining self-reactive $\mathrm{B}$ cells by lack of antigen interaction and hence co-stimulation by $\mathrm{T}$ cells $[17,53]$.

Central B cell tolerance is described as functional in APS-1 patients, reflecting that it is established independently of T cells and their AIRE-dependent selection [26]. The tolerance mechanisms in the periphery are however impaired, resulting in a peripheral accumulation of autoreactive mature naïve B cells. Hence, adequate $T$ cell tolerance is crucial for obtaining optimal peripheral B cell selection. An Aire-deficient mouse model with impairment of the hematologic development of the monocyte linage developed marginal zone B cell (MZB) lymphoma, indicating an exaggerated activation of B cells in AIRE-deficient mice which increased with age [54]. The development of MZB lymphoma has further been linked to increased levels of B cell-activating factor of the TNF family (BAFF) produced by DCs in the periphery upon IFN- $\alpha$ stimulation, highlighting that AIRE regulates T cell-independent $B$ cell responses through BAFF [55]. BAFF was also increased in APS-1 patients in two other reports $[26,56]$ suggesting B cell impairment as this factor is required for peripheral $B$ cell survival and homeostasis and for regulating the expression of the B cell essential receptor CD21.

Number-wise, there are conflicting reports regarding the peripheral B cell subsets found in APS-1 patients. The frequency of CD19+ cells in the blood is reported to be similar to those in controls [57] or slightly fewer [31,56,58]. Sng et al. showed that the B cell subpopulations were in the normal reference range in the AIRE-deficient state, except for the CD19+CD27-CD21-/lo compartment which was expanded [26]. Another study claimed age-dependent lower levels of switched-memory (CD27+ IgM-) B cells, but an increase in CD27+ IgM+ memory B cells [31]. These findings indicate first that the B cell phenotype is significantly altered in APS-1 patients and secondly, that the innate immune system, represented by the circulating MZB cells and the IgM positive B cells, contributes to the disease progression. Specific information about the autoreactive B cells would aid to move the field forward.

\section{Autoantibodies in APS-1}

A hallmark of APS-1 is multiple high-titer circulating autoantibodies, some of which are excellent diagnostic markers of both the disease itself and different disease components (Table 1). The autoantibodies in APS-1 can be classified into two groups: organ-specific autoantibodies as well as systemic autoantibodies against certain cytokines of the immune system itself.

The most common organ-specific autoantigens include 21-hydroxylase $(21 \mathrm{OH})$ correlating to Addison's disease, NOD-like receptor pyrin domain containing 5 (NALP5) associated to both hypoparathyroidism and POI, and side-chain cleavage enzyme (SSC) in females, also linked to ovarian insufficiency [1]. Other autoantibodies are frequently seen although the correlation to specific manifestations is less clear: tyrosine hydroxylase, 
aromatic L-amino acid decarboxylase (AADC) and tryptophan hydroxylase (TPH) [12]. These autoantibodies are useful diagnostic markers in addition to the clinical diagnosis, ensuring an autoimmune component to the disease. Of note, these autoantibodies are also seen in patients with isolated disease components, e.g., the detection of $21 \mathrm{OH}$ in patients with isolated Addison's disease.

The most frequently found autoantibodies target cytokines and have neutralizing properties in vitro. Ninety-five percent of APS-1 patients display autoantibodies against IFN- $\omega$ and IFN- $\alpha$ [59], while interleukin-17 (IL-17) family cytokines, especially IL-22, are targeted in around $90 \%$ of all patients [60], making these excellent screening tools to identify APS-1 patients. Overall, the most common autoantigens in APS-1 are IFN- $\omega$, IL-22 and $21 \mathrm{OH}[2,59]$, which are regularly used as diagnostic tools preceding AIRE sequencing. An overview of APS-1 autoantigens as well as the corresponding clinical manifestations are given in Table 1.

Table 1. Overview of the most important autoantigens and associated clinical manifestations in APS-1.

\begin{tabular}{ccc}
\hline Clinical Manifestation & Autoantigen & Ref \\
\hline Chronic mucocutaneous candidiasis & IL-22, IL-17 & {$[60,61]$} \\
Hypoparathyroidism & NALP5, CaSR & {$[62,63]$} \\
Addison's disease & 21OH & {$[64,65]$} \\
Ovarian failure & SSC, 17OH, NALP5 & {$[66,67]$} \\
Testicular failure & TSGA1, TGM4, PDILT, MAGEB2, SSC & {$[68-70]$} \\
Type 1 diabetes & Insulin, IA2 & {$[71]$} \\
Autoimmune hepatitis & CYP1A2, AADC, TPH & {$[72-74]$} \\
Intestinal malabsorption & TPH & {$[72,74]$} \\
Vitiligo & SOX-9, SOX-10, AADC & {$[75,76]$} \\
Alopecia & TH & {$[77]$} \\
Pulmonary disease & KCNRG, BPIFB1 & {$[78,79]$} \\
Non-organ specific & IFN- $\omega$, IFN- $\alpha 2$, IL-22, IL-17 & {$[60,61,80]$} \\
\hline
\end{tabular}

17OH, 17 hydroxylase; 21OH, 21 hydroxylase; AADC, aromatic L-amino acid decarboxylase; BPIFB1, bactericidal/permeability-increasing fold-containing B1; CYP1A2, Cytochrome P450 1A2; GAD65, glutamic acid decarboxylase 65; IA2, tyrosine phosphatase like protein; IL, interleukin; IFN, interferon; KCNRG, potassium channel regulating protein; MAGEB2, melanoma-associated antigen B2; NALP5, NOD-like receptor pyrin domain containing 5; PDILT, protein disulphide isomerase-like, testis expressed; SOX, SRY-related HMG-box; SSC, side-chain cleavage enzyme; TGM4, transglutaminase 4; TH, tyrosine hydroxylase; TPH, tryptophan hydroxylase.

The autoantibodies seen in APS-1 are a result of the lack of peripheral tolerance as the autoantibodies against IL-17A, IL-17F, and IL-22 amongst others were shown to be present in the bone marrow pool in both APS-1 patients and controls. However, while these markers for autoimmunity were still present in the peripheral B cell pool of APS-1 patients, they were removed in healthy subjects, indicating this essential immune controls step is deficient in APS-1 patients [26]. The mechanisms leading to the high titers of autoantibodies presenting early in life are still unclear. Autoantibodies against IFN- $\omega$ can be found as early as 6 months of age [81], resembling the early presence of autoantibodies in Immune dysregulation, polyendocrinopathy, enteropathy, X-linked (IPEX) syndrome, that are often detectable from birth [82]. Additionally, autoantibodies targeting IFN- $\alpha$ have been reported in a subgroup of IPEX patients [83]. The loss of Tregs and consequently, peripheral $\mathrm{T}$ cell tolerance mechanisms in IPEX patients leads to the accumulation of peripheral B cells and autoantibodies. This underlines the effect loss of T cell tolerance, either central or peripheral, implies on B cell function leading to autoimmune disease and immunodeficiency. The IFN- $\alpha$ autoantibodies have also recently been described in critically ill COVID-19 patients, in comparison to those with uncomplicated disease courses. This study concluded that a B cell autoimmune phenocopy of inborn errors of type I IFN immunity explained life-threatening COVID-19 pneumonia in $2.6 \%$ of females and $12.5 \%$ of males [84]. Looking to APS-1 patients having undergone COVID-19 infection, the picture is less clear, as both mild and severe COVID-19 infections have been reported [85-88]. 
A few antigens have been reported to be targeted by autoantibodies as well as autoreactive T cells. Mapping the autoreactive T cell epitopes is a cumbersome work, in particular in humans where the autoreactive $\mathrm{T}$ cells in circulation often are scarce and the epitopes rely on the HLA genotype. In APS-1 patients, most of the effort has been carried out regarding 21-hydroxylase, where this autoantibody target has also shown to be targeted by autoreactive T cells [89], implying that the B and T cells collaborate on the autoimmune mechanisms causing pathology. In Aire ko mice, this has been shown for the interphotoreceptor retinoid-binding protein (IRBP) [90], as well as for BPI Fold Containing Family B Member 9 (BPIFB9) [79].

\section{B Cells in AIRE-Deficient Mice Varies with Genetic Strain and Aire Mutations}

AIRE-deficient mouse models have been indispensable in elucidating the molecular function of AIRE. Human AIRE and murine Aire share around 77\% nucleotide homology in the coding regions and around 71\% protein homology [91,92]. Several mouse strains like BALB/c, NOD (Non-Obese Diabetic) CD1, TRAMP (TRans-genic Adenocarcinoma of the Mouse Prostate), NIMR (Naval Medical Research Institute), and C57BL/6 mice have been used, and the phenotype of the disease varies from strain to strain (Reviewed in [93]). AIRE-deficient mice develop multiple features that resemble the human corresponding AIRE-deficient phenotype, like multiorgan lymphocytic infiltration, infertility, and the development of circulating autoantibodies against liver and sperm [94]. Nevertheless, even though some components of APS-1 are present, none of the main dyad of CMC, hypoparathyroidism, and Addison's disease, or other apparent endocrinopathies are replicated, and the phenotype is in general surprisingly mild except on the NOD background [54]. This was among others shown by Hubert and colleagues [95], introducing 13-basepair deletion in Aire commonly seen in APS-1 patients on a C57BL/ 6 background, where they found an increase in activation of CD44highCD4+ T cells, while all other $\mathrm{T}$ cell subsets were unaffected. On the same genetic background but with Aire exon 2 and 3 deleted, T cells infiltrating the salivary gland, ovary, and eye, were found [20]. The immune reactions included sporadic infiltration into the sublingual salivary gland as well as severe infiltration in the parotid salivary glands, but no immune cells were seen in the stomach, liver, kidney, epididymis, thyroid, parathyroid, testis, ovary, and epidermis. Interestingly, the lymphocyte infiltration and disease were influenced by the age of these mice [20]. Some of the dominant-negative mutations causing APS-1 in humans have also been introduced in mice. Using mice on the NOD background, the mice showed spontaneous immune infiltrations in the liver, prostate, and salivary glands, with a partially inhibited TRA repertoire and developed neuropathy and early-onset diabetes [96,97], indicating the importance of quantitative changes in thymic antigen expression in the development of organ-specific autoimmunity.

Autoantibodies in AIRE-deficient mice have been detected in oocytes in the ovary, the outer layer of the retina in the eye, and in the parietal cells in the stomach [20]. Autoantibody reactivity is commonly targeting the liver and pancreas, testis, lung, eye, and salivary gland, but no autoantibodies against the major autoantigens in APS-1, including amongst others 21OH, 17OH, SSC, AADC, and TPH, were found in mice lacking Aire [20,98]. A few overlapping targets have however been found in both APS-1 patients and autoimmunity prone mice: The orthologue to NALP5 (MATER) is an autoantigen for a murine model of autoimmune ovarian failure [99-101], and anti-BPIFB1 (bactericidal/permeabilityincreasing fold-containing B1) are present in both APS-1 and one of the AIRE-deficient mouse models $[79,102]$. As the cytokine autoantibodies were discovered in human APS-1 patients in 2006 (against type I interferons) [80] and in 2010 (IL-17 and IL-22) [60,103], these autoantibodies were not analyzed in the first Aire ko mouse models. The first shared cytokine target between AIRE-deficient humans and AIRE-deficient mice was reported by Kärner et al., describing IgG1 neutralizing antibodies to IL-17A in aged AIRE-deficient $\mathrm{BALB} / \mathrm{c}$ mice [104]. 
Although the Aire mouse models differ from humans in several aspects, they have provided invaluable insight into the establishment of immunological tolerance and holds potential for exploring new treatment options targeting the immune system.

\section{Lessons from Other Autoimmune Diseases}

Looking into autoimmune diseases in general, B cells have been found to play several diverse roles. These include both antibody-mediated as well as antibody independent mechanisms, it comprises their function as APCs, their secretion of inflammatory cytokines (e.g., TNF- $\alpha$ and IFN- $\gamma$ ), the modulation of antigen processing and presentation, and the generation of ectopic germinal centers (GCs) and tertiary lymphoid tissues at inflamed sites [105].

In some autoimmune disorders, autoantibodies have been shown to be directly pathogenic. One such example is Graves' disease. In this disorder, the hyperthyroid state is triggered by autoantibody binding to and stimulating the thyrotropin (TSH) receptor, subsequently causing an increased release of thyroid hormones [106,107]. Autoantibodies can also exert an inhibitory effect on receptor functions as seen in Myasthenia gravis where they bind to acetylcholine receptors (AChRs) and efficiently block neurotransmission [108].

The importance of B cells as coordinators of the T cell functions is evident in several mouse models of autoimmune diseases. In a model of autoimmune hepatitis, known as a prototypic T cell-mediated disease, $\mathrm{B}$ cell depletion correlated with a decrease in the amount of CD4+ and CD8+ T effector cells with a significantly inhibited memory CD8+ $T$ cell subset [109]. In mouse models of both rheumatoid arthritis and T1D, the lack of antigen-presenting $B$ cells led to a milder disease highlighting the role of $B$ cells in T cell activation [109-111]. B cells can also modulate antigen processing and presentation, thus indirectly affecting the subset of autoreactive T cells [112-114]. The secretion of inflammatory cytokines by B cells exerts a regulatory influence on T cells providing feedback stimulation leading to further B cell activation. This subsequently led to modulation of DC migration and activation of macrophages $[115,116]$. B cells can further be involved in lymphoid tissue genesis and the generation of ectopic GCs. This has been described for example in T1D, Graves' disease, Sjögren's syndrome and rheumatoid arthritis [117,118].

Recently, the identification of a B cell subpopulation with immunosuppressive capacity that downregulates immune responses and supports immunological tolerance has been characterized in several autoimmune diseases. Unlike Tregs, a specific transcription factor for regulatory B cells (Bregs) has not been discovered, and their identification relies solely on their capacity to inhibit $\mathrm{T}$ cell activation and cytokine secretion $[119,120]$. However, like for Tregs, the production of IL-10 and IL-35 are thought to be the main method of suppression [121]. In patients with T1D the IL-10 positive B cells are shown to produce less IL-10 in vitro [122], and IL-10 production from activated B cells delayed disease onset in young NOD mice [123]. Additionally, in autoimmune hyper- and hypothyroidism, Bregs are found to be decreased in numbers when compared to healthy controls [124], although functional studies are still needed to understand their detailed impact on pathology and tolerance. Importantly, Bregs can be induced by both adaptive and innate immune signals [125], and their functional ability to prevent autoimmune inflammation has been shown in mouse models [126]. Building on information from other autoimmune diseases might be a good strategy to understand APS-1 and vice versa.

\section{Treatment Approaches Targeting B Cells in Autoimmune Diseases}

Many current treatment options of autoimmune diseases that focus on B cells include monoclonal antibodies against surface markers which lead to B cell depletion. The most prominent examples are antibodies targeting CD19 (e.g., Obexelimab or Inebilizumab), CD20 (e.g., Rituximab) and CD22 (e.g., Epratuzumab). There are also further promising, but less used surface targets like CD52 (Alemtuzumab), which is efficient for the treatment of multiple sclerosis (MS) $[127,128]$. CD19 is expressed on B cells of all maturation stages from the pro-B cell stage until late stages of plasma cells, and classical monoclonal CD19 an- 
tibodies are for example applied for the treatment of MS (Inebilizumab) [129,130]. Targeting of CD20 leads to a depletion of mature naïve and memory B cells as wells as an inhibition of the development of short-lived plasma cells, although does not have as broad an effect as anti-CD19 treatment. Rituximab is used (partially off-label) for several autoimmune diseases like rheumatoid arthritis, T1D, MS, and systemic lupus erythematosus [131-134], but is also frequently used for research on B cells in autoimmune diseases. It was found to reduce IgM levels whilst not affecting levels of circulating IgG $[135,136]$. However, this does not apply to all autoimmune diseases since the reduction in IgG autoantibody titres has also been reported [137]. The antibody-independent effect of Rituximab is thought to be related to the elimination of B cells as APCs leading to a reduced stimulation of T cells [138,139].

Besides classical monoclonal antibody B cell depletion, other approaches can achieve an antigen-specific B cell depletion by redirecting $\mathrm{T}$ cells. This approach has been explored in Myasthenia gravis. This is a rare, but often severe, disorder of neuromuscular transmission causing fatigable muscle weakness. It is mostly due to antibodies directed against the AChR, but in a proportion of patients without AChR antibodies, antibodies to muscle-specific tyrosine kinase (MuSK) are found [140]. Like AChR, MuSK is also a membrane protein playing an essential role at the neuromuscular junction. By generating chimeric autoantibody receptor (CAAR) T cells expressing MuSK, MuSK reactive memory B cells were specifically eliminated by the CAAR T cells [141,142]. Other approaches aiming at a selective depletion of B cells are being developed, including the elimination of autoantigen-specific B cells by coupling autoantigens to magnetic nanoparticles and subsequent removal of these autoantigen-specific B cells through extracorporeal filtration [143]. The ultimate goal would be the selective depletion of B cells except for Bregs. Although still in its infancy, CD19-targeted CAR regulatory T cells have been established to suppress $B$ cell pathologies. When injecting these into immunodeficient mice reconstituted with human PBMCs, recovery of graft-versus-host disease was observed [144].

Other treatment approaches focus on neutralizing factors involved in survival or activation of B cells, like BAFF, a proliferation-inducing ligand (APRIL), or transmembrane activator and calcium-modulator and cyclophilin ligand interactor (TACI) [145-147]. For example, elevated levels of BAFF have been observed in Sjogren's syndrome, rheumatoid arthritis, and systemic lupus erythematosus. Inhibition of BAFF reduced the symptoms in autoimmune animal models $[148,149]$, as well as in patients $[145,146]$. Belimumab, a recombinant human monoclonal antibody inhibiting BAFF, has amongst others been evaluated in an international trial involving 448 patients with systemic lupus erythematosus. Belimumab together with standard therapies for lupus nephritis enhanced renal responses and reduced the risk of renal-related events by $50 \%$ among patients [150]. There are currently 24 studies with Belimumab registered as "recruiting" or "not yet recruiting" at cliniclatrials.gov, most of which investigate systemic lupus erythematosus. Atacicept is a recombinant fusion protein of the binding portion of the TACI (transmembrane activator and CAML interactor) receptor that neutralizes BAFF and APRIL simultaneously. It is being tested in several autoimmune diseases, including MS and rheumatoid arthritis, but without any noticeable effects so far [151]. Inhibition of B cell activation by blocking the CD40/CD40L interaction of B and T cells was recognized as a possible target in a mouse model of lupus [152,153] but has not yet evolved into human trials.

Therapies have also been developed to induce apoptosis of B cell anergy by targeting the BCR or BCR-associated transmembrane signaling proteins like CD79 [154] or target kinases involved in BCR signaling [155], so far only tested in mouse model systems. Potential further targets might include inflammatory cytokines released by the B cells, like IL-6, TNF- $\alpha$ or IFN- $\alpha$ [145], or the lymphotoxin- $\beta$ receptor to inhibit the formation of ectopic GCs [156] (Figure 1). The use and development of B cell-specific therapies will be interesting to follow and holds the potential to ameliorate several autoimmune disorders, providing treatment beyond the regular substitution medication. 


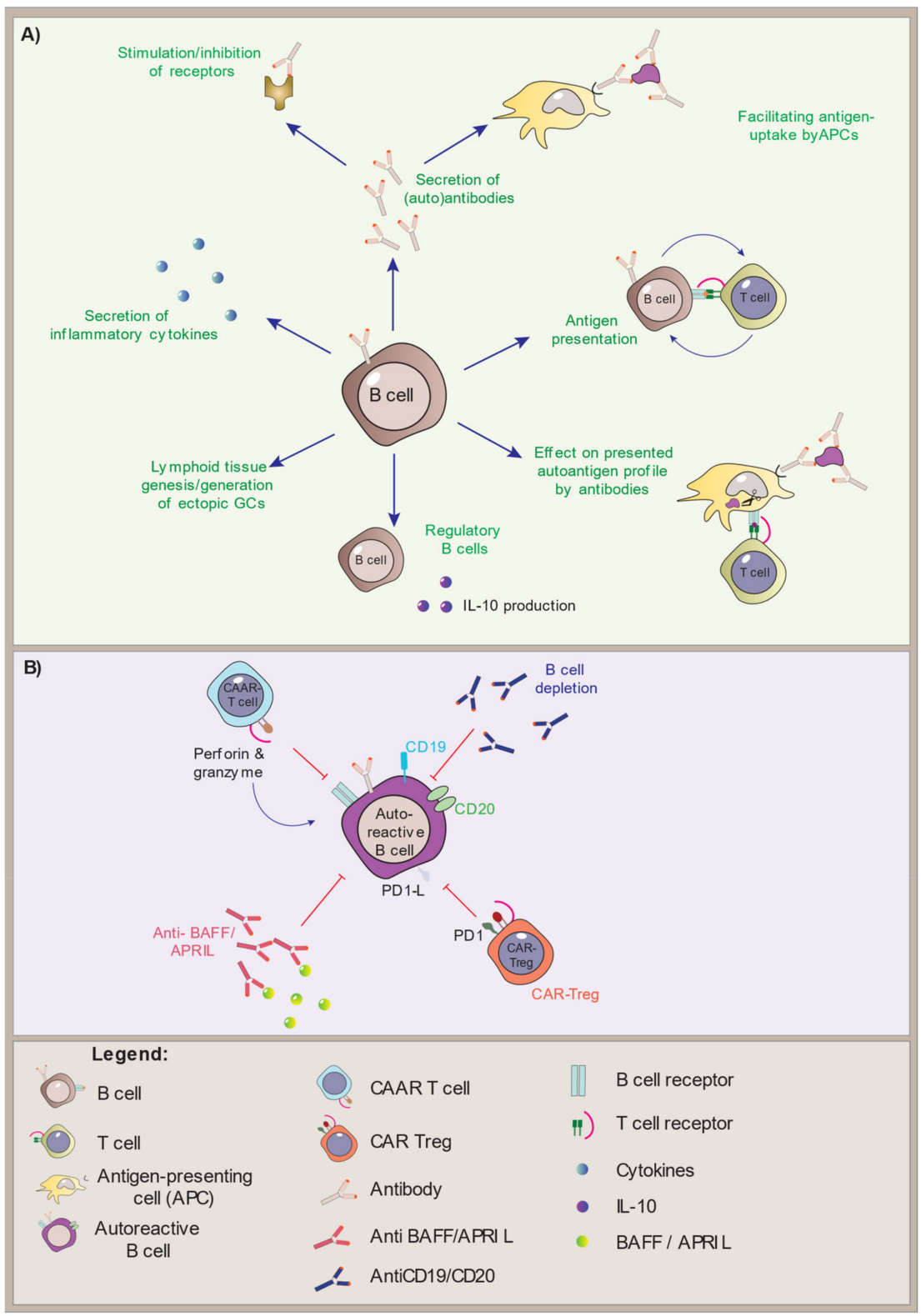

Figure 1. B cell function and modes of intervention. (A) The effector functions of B cells in the immune system, including the IL-10 producing regulatory B cells. (B) Modes of B cell depletion. Antibodies directed against the B cell-specific markers CD19 and CD20 will deplete all B cells, while chimeric auto-antibody receptor T (CAAR-T) cells and chimeric antibody receptor (CAR)-Tregs can be specifically targeted to autoreactive B cells.

\section{Conclusions and Future Perspectives}

APS-1 is a severe disease where mutations in the AIRE gene lead to the accumulation of autoimmune manifestations, mainly in the endocrine organs. It is a rare disease but has proved to be a powerful model shedding light on the mechanisms of thymic negative selection of T cells. Although the disease is mainly shown to be T cell-driven, accumulating evidence points to an aberrant immune reaction involving B cells. In particular, peripheral $\mathrm{B}$ cell tolerance is compromised resulting in the production of autoantibodies, aberrant $\mathrm{T}$ cell activation, and skewing of $\mathrm{B}$ cell populations. Modulation of $\mathrm{B}$ cell mechanisms has had beneficial effects on autoimmune diseases both in humans and mouse models, highlighting their potential for immunotherapies. They might have a better safety profile than T cell-directed therapies. Combining B and T cell-directed therapies is also a possibility. Nevertheless, detailed information on how the B cell subsets and BCR repertoire behaves 
in APS-1, functional studies, and explorations on how these cells react to different kinds of immune-modulatory drugs is crucial if we want to target the autoimmune process in APS-1 specifically, for example, to eliminate the self-reactive cells. Research questions to prioritize:

- What is the inflammatory cytokine secretion profile of B cells in APS-1 patients?

- How do B cells in APS-1 patients interact with T cells, DCs, and macrophages, especially with regards to antigen presentation?

- Is the Breg subset functional in APS-1?

- Are the hallmark autoantibodies in plasma and sera from APS-1 patients pathogenic?

- Does B cell depletion therapy improve the main manifestations, and does it impact the interferon profile?

Author Contributions: A.S.B.W. took part in the disposition and the writing of the paper and has read and agreed to the final version. S.B. drafted the first version of the manuscript and took part in writing and agreed to the final version. E.S.H. took part in writing the paper and agreed to the final version. B.E.O. conceived the idea, took part in writing the paper and has agreed to the published version of the manuscript. All authors have read and agreed to the published version of the manuscript.

Funding: The authors acknowledge the KG Jebsen Foundation, University of Bergen, The Western Norway Health Authorities, and the Norwegian Research Council for funding.

Institutional Review Board Statement: Not applicable.

Informed Consent Statement: Not applicable.

Conflicts of Interest: The authors declare no conflict of interest.

\section{References}

1. Husebye, E.S.; Anderson, M.S.; Kämpe, O. Autoimmune Polyendocrine Syndromes. N. Engl. J. Med. 2018, 378, 1132-1141. [CrossRef]

2. Wolff, A.S.B.; Erichsen, M.M.; Meager, A.; Magitta, N.F.; Myhre, A.G.; Bollerslev, J.; Fougner, K.J.; Lima, K.; Knappskog, P.M.; Husebye, E.S. Autoimmune Polyendocrine Syndrome Type 1 in Norway: Phenotypic Variation, Autoantibodies, and Novel Mutations in the Autoimmune Regulator Gene. J. Clin. Endocrinol. Metab. 2007, 92, 595-603. [CrossRef]

3. Ahonen, P.; Myllärniemi, S.; Sipilä, I.; Perheentupa, J. Clinical Variation of Autoimmune Polyendocrinopathy-CandidiasisEctodermal Dystrophy (APECED) in a Series of 68 Patients. N. Engl. J. Med. 1990, 322, 1829-1836. [CrossRef]

4. Perheentupa, J. Autoimmune Polyendocrinopathy-Candidiasis-Ectodermal Dystrophy. J. Clin. Endocrinol. Metab. 2006, 91, 2843-2850. [CrossRef] [PubMed]

5. Zlotogora, J.; Shapiro, M.S. Polyglandular autoimmune syndrome type I among Iranian Jews. J. Med. Genet. 1992, 29, 824-826. [CrossRef] [PubMed]

6. Guo, C.-J.; Leung, P.S.; Zhang, W.; Ma, X.; Gershwin, M.E. The immunobiology and clinical features of type 1 autoimmune polyglandular syndrome (APS-1). Autoimmun. Rev. 2018, 17, 78-85. [CrossRef]

7. Meloni, A.; Furcas, M.; Cetani, F.; Marcocci, C.; Falorni, A.; Perniola, R.; Pura, M.; Wolff, A.S.B.; Husebye, E.S.; Lilic, D.; et al. Autoantibodies against Type I Interferons as an Additional Diagnostic Criterion for Autoimmune Polyendocrine Syndrome Type I. J. Clin. Endocrinol. Metab. 2008, 93, 4389-4397. [CrossRef] [PubMed]

8. $\quad$ Aaltonen, J.; Björses, P.; Perheentupa, J.; Horelli-Kuitunen, N.; Palotie, A.; Peltonen, L.; Lee, Y.S.; Francis, F.; Henning, S.; Thiel, C.; et al. An autoimmune disease, APECED, caused by mutations in a novel gene featuring two PHD-type zinc-finger domains. Nat. Genet. 1997, 17, 399-403. [CrossRef]

9. Nagamine, K.; Peterson, P.; Scott, H.; Kudoh, J.; Minoshima, S.; Heino, M.; Krohn, K.J.E.; Lalioti, M.D.; Mullis, P.E.; Antonarakis, S.; et al. Positional cloning of the APECED gene. Nat. Genet. 1997, 17, 393-398. [CrossRef]

10. Oftedal, B.; Hellesen, A.; Erichsen, M.M.; Bratland, E.; Vardi, A.; Perheentupa, J.; Kemp, E.H.; Fiskerstrand, T.; Viken, M.K.; Weetman, A.P.; et al. Dominant Mutations in the Autoimmune Regulator AIRE Are Associated with Common Organ-Specific Autoimmune Diseases. Immunity 2015, 42, 1185-1196. [CrossRef]

11. Cetani, F.; Barbesino, G.; Borsari, S.; Pardi, E.; Cianferotti, L.; Pinchera, A.; Marcocci, C. A Novel Mutation of the Autoimmune Regulator Gene in an Italian Kindred with Autoimmune Polyendocrinopathy-Candidiasis-Ectodermal Dystrophy, Acting in a Dominant Fashion and Strongly Cosegregating with Hypothyroid Autoimmune Thyroiditis. J. Clin. Endocrinol. Metab. 2001, 86, 4747-4752. [CrossRef]

12. Abramson, J.; Husebye, E.S. Autoimmune regulator and self-tolerance - molecular and clinical aspects. Immunol. Rev. 2016, 271, 127-140. [CrossRef] 
13. Bruserud, Ø.; Oftedal, B.E.; Wolff, A.B.; Husebye, E.S. AIRE-mutations and autoimmune disease. Curr. Opin. Immunol. 2016, 43, 8-15. [CrossRef] [PubMed]

14. Björses, P.; Halonen, M.; Palvimo, J.; Kolmer, M.; Aaltonen, J.; Ellonen, P.; Perheentupa, J.; Ulmanen, I.; Peltonen, L. Mutations in the AIRE Gene: Effects on Subcellular Location and Transactivation Function of the Autoimmune PolyendocrinopathyCandidiasis-Ectodermal Dystrophy Protein. Am. J. Hum. Genet. 2000, 66, 378-392. [CrossRef]

15. Stolarski, B.; Pronicka, E.; Korniszewski, L.; Pollak, A.; Kostrzewa, G.; Rowińska, E.; Włodarski, P.; Skórka, A.; Gremida, M.; Krajewski, P.; et al. Molecular background of polyendocrinopathy-candidiasis-ectodermal dystrophy syndrome in a Polish population: Novel AIRE mutations and an estimate of disease prevalence. Clin. Genet. 2006, 70, 348-354. [CrossRef]

16. Pearce, S.H.; Cheetham, T.; Imrie, H.; Vaidya, B.; Barnes, N.D.; Bilous, R.W.; Carr, D.; Meeran, K.; Shaw, N.J.; Smith, C.S.; et al. A Common and Recurrent 13-bp Deletion in the Autoimmune Regulator Gene in British Kindreds with Autoimmune Polyendocrinopathy Type 1. Am. J. Hum. Genet. 1998, 63, 1675-1684. [CrossRef]

17. Goodnow, C.; Sprent, J.; Groth, B.F.D.S.; Vinuesa, C. Cellular and genetic mechanisms of self tolerance and autoimmunity. Nat. Cell Biol. 2005, 435, 590-597. [CrossRef] [PubMed]

18. Anderson, M.S.; Venanzi, E.; Chen, Z.; Berzins, S.P.; Benoist, C.; Mathis, D. The Cellular Mechanism of Aire Control of T Cell Tolerance. Immunity 2005, 23, 227-239. [CrossRef] [PubMed]

19. Takahama, Y. Journey through the thymus: Stromal guides for T-cell development and selection. Nat. Rev. Immunol. 2006, 6, 127-135. [CrossRef] [PubMed]

20. Anderson, M.S.; Venanzi, E.S.; Klein, L.; Chen, Z.; Berzins, S.P.; Turley, S.J.; von Boehmer, H.; Bronson, R.; Dierich, A.; Benoist, C.; et al. Projection of an Immunological Self Shadow Within the Thymus by the Aire Protein. Science 2002, 298, 1395-1401. [CrossRef]

21. Sansom, S.N.; Shikama-Dorn, N.; Zhanybekova, S.; Nusspaumer, G.; Macaulay, I.; Deadman, M.E.; Heger, A.; Ponting, C.; Holländer, G.A. Population and single-cell genomics reveal theAiredependency, relief from Polycomb silencing, and distribution of self-antigen expression in thymic epithelia. Genome Res. 2014, 24, 1918-1931. [CrossRef]

22. Cowan, J.E.; Baik, S.; McCarthy, N.I.; Parnell, S.M.; White, A.J.; Jenkinson, W.E.; Anderson, G. Aire controls the recirculation of murine Foxp3+regulatory T-cells back to the thymus. Eur. J. Immunol. 2018, 48, 844-854. [CrossRef] [PubMed]

23. Malchow, S.; Leventhal, D.S.; Lee, V.; Nishi, S.; Socci, N.D.; Savage, P.A. Aire Enforces Immune Tolerance by Directing Autoreactive T Cells into the Regulatory T Cell Lineage. Immunity 2016, 44, 1102-1113. [CrossRef]

24. Yang, S.; Fujikado, N.; Kolodin, D.; Benoist, C.; Mathis, D. Regulatory T cells generated early in life play a distinct role in maintaining self-tolerance. Science 2015, 348, 589-594. [CrossRef] [PubMed]

25. Zhang, X.; Li, X.C.; Xiao, X.; Sun, R.; Tian, Z.; Wei, H. CD4+CD62L+ Central Memory T Cells Can Be Converted to Foxp3+ T Cells. PLoS ONE 2013, 8, e77322. [CrossRef]

26. Sng, J.; Ayoglu, B.; Chen, J.W.; Schickel, J.-N.; Ferre, E.M.N.; Glauzy, S.; Romberg, N.; Hoenig, M.; Cunningham-Rundles, C.; Utz, P.J.; et al. AIRE expression controls the peripheral selection of autoreactive B cells. Sci. Immunol. 2019, 4, eaav6778. [CrossRef]

27. Koivula, T.-T.; Laakso, S.M.; Niemi, H.J.; Kekäläinen, E.; Laine, P.; Paulin, L.; Auvinen, P.; Arstila, T.P. Clonal Analysis of Regulatory T Cell Defect in Patients with Autoimmune Polyendocrine Syndrome Type 1 Suggests Intrathymic Impairment. Scand. J. Immunol. 2017, 86, 221-228. [CrossRef] [PubMed]

28. Gies, V.; Guffroy, A.; Danion, F.; Billaud, P.; Keime, C.; Fauny, J.-D.; Susini, S.; Soley, A.; Martin, T.; Pasquali, J.-L.; et al. B cells differentiate in human thymus and express AIRE. J. Allergy Clin. Immunol. 2017, 139, 1049-1052.e12. [CrossRef] [PubMed]

29. Yamano, T.; Nedjic, J.; Hinterberger, M.; Steinert, M.; Koser, S.; Pinto, S.; Gerdes, N.; Lutgens, E.; Ishimaru, N.; Busslinger, M.; et al. Thymic B Cells Are Licensed to Present Self Antigens for Central T Cell Tolerance Induction. Immunity 2015, 42, $1048-1061$. [CrossRef]

30. Suzuki, E.; Kobayashi, Y.; Kawano, O.; Endo, K.; Haneda, H.; Yukiue, H.; Sasaki, H.; Yano, M.; Maeda, M.; Fujii, Y. Expression of AIRE in thymocytes and peripheral lymphocytes. Autoimmunity 2008, 41, 133-139. [CrossRef]

31. Perri, V.; Gianchecchi, E.; Scarpa, R.; Valenzise, M.; Rosado, M.M.; Giorda, E.; Crinò, A.; Cappa, M.; Barollo, S.; Garelli, S.; et al. Altered B cell homeostasis and Toll-like receptor 9-driven response in patients affected by autoimmune polyglandular syndrome Type 1. Immunobiology 2017, 222, 372-383. [CrossRef] [PubMed]

32. Zhao, B.; Chang, L.; Fu, H.; Sun, G.; Yang, W. The Role of Autoimmune Regulator (AIRE) in Peripheral Tolerance. J. Immunol. Res. 2018, 2018. [CrossRef]

33. Zhu, W.; Yang, W.; He, Z.; Liao, X.; Wu, J.; Sun, J.; Yang, Y.; Li, Y. Overexpressing autoimmune regulator regulates the expression of toll-like receptors by interacting with their promoters in RAW264.7 cells. Cell. Immunol. 2011, 270, 156-163. [CrossRef] [PubMed]

34. Gavanescu, I.; Benoist, C.; Mathis, D. B cells are required for Aire-deficient mice to develop multi-organ autoinflammation: A therapeutic approach for APECED patients. Proc. Natl. Acad. Sci. USA 2008, 105, 13009-13014. [CrossRef]

35. Popler, J.; Alimohammadi, M.; Kämpe, O.; Dalin, F.; Dishop, M.K.; Barker, J.M.; Moriarty-Kelsey, M.; Soep, J.B.; Deterding, R.R. Autoimmune polyendocrine syndrome type 1: Utility of KCNRG autoantibodies as a marker of active pulmonary disease and successful treatment with rituximab. Pediatr. Pulmonol. 2011, 47, 84-87. [CrossRef]

36. Kato, A.; Hulse, K.; Tan, B.K.; Schleimer, R.P. B-lymphocyte lineage cells and the respiratory system. J. Allergy Clin. Immunol. 2013, 131, 933-957. [CrossRef] 
37. Napier, C.; Gan, E.H.; Mitchell, A.L.; Gilligan, L.C.; Rees, D.A.; Moran, C.; Chatterjee, K.; Vaidya, B.; James, R.A.; Mamoojee, Y.; et al. Residual Adrenal Function in Autoimmune Addison's Disease-Effect of Dual Therapy With Rituximab and Depot Tetracosactide. J. Clin. Endocrinol. Metab. 2019, 105, e1250-e1259. [CrossRef] [PubMed]

38. Pearce, S.H.S.; Mitchell, A.L.; Bennett, S.; King, P.; Chandran, S.; Nag, S.; Chen, S.; Smith, B.R.; Isaacs, J.; Vaidya, B. Adrenal Steroidogenesis after B Lymphocyte Depletion Therapy in New-Onset Addison's Disease. J. Clin. Endocrinol. Metab. 2012, 97, E1927-E1932. [CrossRef] [PubMed]

39. Devoss, J.J.; Shum, A.K.; Johannes, K.P.A.; Lu, W.; Krawisz, A.K.; Wang, P.; Yang, T.; LeClair, N.P.; Austin, C.; Strauss, E.C.; et al. Effector Mechanisms of the Autoimmune Syndrome in the Murine Model of Autoimmune Polyglandular Syndrome Type 1. J. Immunol. 2008, 181, 4072-4079. [CrossRef]

40. Delves, P.J.; Roitt, I.M. The Immune System. N. Engl. J. Med. 2000, 343, 108-117. [CrossRef]

41. Petersone, L.; Edner, N.M.; Ovcinnikovs, V.; Heuts, F.; Ross, E.M.; Ntavli, E.; Wang, C.J.; Walker, L.S.K. T Cell/B Cell Collaboration and Autoimmunity: An Intimate Relationship. Front. Immunol. 2018, 9, 1941. [CrossRef]

42. Akashi, K.; Richie, L.I.; Miyamoto, T.; Carr, W.H.; Weissman, I.L. B Lymphopoiesis in the Thymus. J. Immunol. 2000, 164, 5221-5226. [CrossRef]

43. Ceredig, R. The ontogeny of B cells in the thymus of normal, CD3 $\varepsilon$ knockout (KO), RAG-2 KO and IL-7 transgenic mice. Int. Immunol. 2002, 14, 87-99. [CrossRef]

44. Isaacson, P.; Norton, A.; Addis, B. The human thymus contains a novel population of B lymphocytes. Lancet 1987, 330, 1488-1491. [CrossRef]

45. Miyama-Inaba, M.; Kuma, S.; Inaba, K.; Ogata, H.; Iwai, H.; Yasumizu, R.; Muramatsu, S.; Steinman, R.M.; Ikehara, S. Unusual phenotype of B cells in the thymus of normal mice. J. Exp. Med. 1988, 168, 811-816. [CrossRef] [PubMed]

46. Mori, S.; Inaba, M.; Sugihara, A.; Taketani, S.; Doi, H.; Fukuba, Y.; Yamamoto, Y.; Adachi, Y.; Inaba, K.; Fukuhara, S.; et al. Presence of B cell progenitors in the thymus. J. Immunol. 1997, 158, 4193-4199.

47. Perera, J.; Meng, L.; Meng, F.; Huang, H. Autoreactive thymic B cells are efficient antigen-presenting cells of cognate self-antigens for T cell negative selection. Proc. Natl. Acad. Sci. USA 2013, 110, 17011-17016. [CrossRef] [PubMed]

48. Walters, S.N.; Webster, K.E.; Daley, S.; Grey, S.T. A Role for Intrathymic B Cells in the Generation of Natural Regulatory T Cells. J. Immunol. 2014, 193, 170-176. [CrossRef] [PubMed]

49. Xing, C.; Ma, N.; Xiaoqian, W.; Wang, X.; Zheng, M.; Han, G.; Chen, G.; Hou, C.; Shen, B.; Li, Y.; et al. Critical role for thymic CD19+CD5+CD1dhilL-10+regulatory B cells in immune homeostasis. J. Leukoc. Biol. 2015, 97, 547-556. [CrossRef] [PubMed]

50. Cepeda, S.; Cantu, C.; Orozco, S.; Xiao, Y.; Brown, Z.; Semwal, M.K.; Venables, T.; Anderson, M.S.; Griffith, A.V. Age-Associated Decline in Thymic B Cell Expression of Aire and Aire-Dependent Self-Antigens. Cell Rep. 2018, 22, 1276-1287. [CrossRef]

51. Nemazee, D. Mechanisms of central tolerance for B cells. Nat. Rev. Immunol. 2017, 17, 281-294. [CrossRef]

52. Murphy, K.; Travers, P.; Walport, M. Janeway's Immunobiology, 7th ed.; Garland Science/Taylor \& Francis Group: New York, NY, USA, 1999; pp. 364-368.

53. Tobón, G.J.; Izquierdo, J.H.; Cañas, C.A. B Lymphocytes: Development, Tolerance, and Their Role in Autoimmunity—Focus on Systemic Lupus Erythematosus. Autoimmune Dis. 2013, 2013. [CrossRef]

54. Hässler, S.; Ramsey, C.; Karlsson, M.C.; Larsson, D.; Herrmann, B.; Rozell, B.; Backheden, M.; Peltonen, L.; Kämpe, O.; Winqvist, O. Aire-deficient mice develop hematopoetic irregularities and marginal zone B-cell lymphoma. Blood 2006, 108, 1941-1948. [CrossRef]

55. Lindh, E.; Lind, S.M.; Lindmark, E.; Hässler, S.; Perheentupa, J.; Peltonen, L.; Winqvist, O.; Karlsson, M.C.I. AIRE regulates T-cell-independent B-cell responses through BAFF. Proc. Natl. Acad. Sci. USA 2008, 105, 18466-18471. [CrossRef]

56. Magnani, A.; Meloni, A.; Gattorno, M.; Martini, A.; Traggiai, E. B cell subsets phenotype in autoimmunity with immunodeficiency: Analysis of a cohort of patients with APECED syndrome. Pediatr. Rheumatol. 2011, 9, P285. [CrossRef]

57. Wolff, A.S.B.; Oftedal, B.E.V.; Kisand, K.; Ersvaer, E.; Lima, K.; Husebye, E.S.; Ersvær, E. Flow Cytometry Study of Blood Cell Subtypes Reflects Autoimmune and Inflammatory Processes in Autoimmune Polyendocrine Syndrome Type I. Scand. J. Immunol. 2010, 71, 459-467. [CrossRef] [PubMed]

58. Perniola, R.; Lobreglio, G.; Rosatelli, M.C.; Pitotti, E.; Accogli, E.; De Rinaldis, C. Immunophenotypic Characterisation of Peripheral Blood Lymphocytes in Autoimmune Polyglandular Syndrome Type 1: Clinical Study and Review of the Literature. J. Pediatr. Endocrinol. Metab. 2005, 18, 155-164. [CrossRef] [PubMed]

59. Bruserud, Ø.; Oftedal, B.; Landegren, N.; Erichsen, M.M.; Bratland, E.; Lima, K.; Jørgensen, A.P.; Myhre, A.G.; Svartberg, J.; Fougner, K.J.; et al. A Longitudinal Follow-up of Autoimmune Polyendocrine Syndrome Type 1. J. Clin. Endocrinol. Metab. 2016, 101, 2975-2983. [CrossRef]

60. Kisand, K.; Wolff, A.S.B.; Podkrajsek, K.T.; Tserel, L.; Link, M.; Kisand, K.; Ersvaer, E.; Perheentupa, J.; Erichsen, M.M.; Bratanic, N.; et al. Chronic mucocutaneous candidiasis in APECED or thymoma patients correlates with autoimmunity to Th17-associated cytokines. J. Exp. Med. 2010, 207, 299-308. [CrossRef] [PubMed]

61. Puel, A.; Cypowyj, S.; Bustamante, J.; Wright, J.F.; Liu, L.; Lim, H.K.; Migaud, M.; Israel, L.; Chrabieh, M.; Audry, M.; et al. Chronic Mucocutaneous Candidiasis in Humans with Inborn Errors of Interleukin-17 Immunity. Science 2011, 332, 65-68. [CrossRef] [PubMed] 
62. Alimohammadi, M.; Björklund, P.; Hallgren, Å.; Pöntynen, N.; Szinnai, G.; Shikama, N.; Keller, M.P.; Ekwall, O.; Kinkel, S.A.; Husebye, E.S.; et al. Autoimmune Polyendocrine Syndrome Type 1 and NALP5, a Parathyroid Autoantigen. N. Engl. J. Med. 2008, 358, 1018-1028. [CrossRef]

63. Habibullah, M.; Porter, J.A.; Kluger, N.; Ranki, A.; Krohn, K.J.E.; Brandi, M.L.; Brown, E.M.; Weetman, A.P.; Kemp, E.H. CalciumSensing Receptor Autoantibodies in Patients with Autoimmune Polyendocrine Syndrome Type 1: Epitopes, Specificity, Functional Affinity, IgG Subclass, and Effects on Receptor Activity. J. Immunol. 2018, 201, 3175-3183. [CrossRef]

64. Winqvist, O.; Karlsson, F.; Kämpe, O. 21-hydroxylase, a major autoantigen in idiopathic Addison's disease. Lancet 1992, 339, 1559-1562. [CrossRef]

65. Wolff, A.B.; Breivik, L.; Hufthammer, K.O.; Grytaas, M.A.; Bratland, E.; Husebye, E.S.; Oftedal, B.E. The natural history of 21-hydroxylase autoantibodies in autoimmune Addison's disease. Eur. J. Endocrinol. 2021, 184, 607-615. [CrossRef]

66. Brozzetti, A.; Alimohammadi, M.; Morelli, S.; Minarelli, V.; Hallgren, Å.; Giordano, R.; De Bellis, A.; Perniola, R.; Kämpe, O.; Falorni, A.; et al. Autoantibody Response Against NALP5/MATER in Primary Ovarian Insufficiency and in Autoimmune Addison's Disease. J. Clin. Endocrinol. Metab. 2015, 100, 1941-1948. [CrossRef]

67. Winqvist, O.; Gebre-Medhin, G.; Gustafsson, J.; Ritzén, E.M.; Lundkvist, O.; A Karlsson, F.; Kämpe, O. Identification of the main gonadal autoantigens in patients with adrenal insufficiency and associated ovarian failure. J. Clin. Endocrinol. Metab. 1995, 80, 1717-1723. [CrossRef]

68. Fishman, D.; Kisand, K.; Hertel, C.; Rothe, M.; Remm, A.; Pihlap, M.; Adler, P.; Vilo, J.; Peet, A.; Meloni, A.; et al. Autoantibody Repertoire in APECED Patients Targets Two Distinct Subgroups of Proteins. Front. Immunol. 2017, 8, 976. [CrossRef] [PubMed]

69. Landegren, N.; Sharon, N.; Freyhult, E.; Hallgren, Å.; Eriksson, D.; Edqvist, P.-H.; Bensing, S.; Wahlberg, J.; Nelson, L.M.; Gustafsson, J.; et al. Proteome-wide survey of the autoimmune target repertoire in autoimmune polyendocrine syndrome type 1. Sci. Rep. 2016, 6, 20104. [CrossRef]

70. Reimand, K.; Perheentupa, J.; Link, M.; Krohn, K.; Peterson, P.; Uibo, R. Testis-expressed protein TSGA10 - an auto-antigen in autoimmune polyendocrine syndrome type I. Int. Immunol. 2008, 20, 39-44. [CrossRef]

71. Söderbergh, A.; Myhre, A.G.; Ekwall, O.; Gebre-Medhin, G.; Hedstrand, H.; Landgren, E.; Miettinen, A.; Eskelin, P.; Halonen, M.; Tuomi, T.; et al. Prevalence and Clinical Associations of 10 Defined Autoantibodies in Autoimmune Polyendocrine Syndrome Type I. J. Clin. Endocrinol. Metab. 2004, 89, 557-562. [CrossRef] [PubMed]

72. Ekwall, O.; Sjöberg, K.; Mirakian, R.; Rorsman, F.; Kämpe, O. Tryptophan hydroxylase autoantibodies and intestinal disease in autoimmune polyendocrine syndrome type 1. Lancet 1999, 354, 568. [CrossRef]

73. Gebre-Medhin, G.; Husebye, E.; Gustafsson, J.; Winqvist, O.; Goksøyr, A.; Rorsman, F.; Kämpe, O. Cytochrome P450IA2 and aromaticl-amino acid decarboxylase are hepatic autoantigens in autoimmune polyendocrine syndrome type I. FEBS Lett. 1997, 412, 439-445. [CrossRef]

74. Scarpa, R.; Alaggio, R.; Norberto, L.; Furmaniak, J.; Chen, S.; Smith, B.R.; Masiero, S.; Morlin, L.; Plebani, M.; De Luca, F.; et al. Tryptophan Hydroxylase Autoantibodies as Markers of a Distinct Autoimmune Gastrointestinal Component of Autoimmune Polyendocrine Syndrome Type 1. J. Clin. Endocrinol. Metab. 2013, 98, 704-712. [CrossRef] [PubMed]

75. Hedstrand, H.; Ekwall, O.; Olsson, M.J.; Landgren, E.; Kemp, E.H.; Weetman, A.P.; Perheentupa, J.; Husebye, E.; Gustafsson, J.; Betterle, C.; et al. The Transcription Factors SOX9 and SOX10 Are Vitiligo Autoantigens in Autoimmune Polyendocrine Syndrome Type I. J. Biol. Chem. 2001, 276, 35390-35395. [CrossRef]

76. Husebye, E.S. Autoantibodies against Aromatic L-Amino Acid Decarboxylase in Autoimmune Polyendocrine Syndrome Type I. J. Clin. Endocrinol. Metab. 1997, 82, 147-150. [CrossRef]

77. Hedstrand, H.; Ekwall, O.; Haavik, J.; Landgren, E.; Betterle, C.; Perheentupa, J.; Gustafsson, J.; Husebye, E.; Rorsman, F.; Kämpe, O. Identification of Tyrosine Hydroxylase as an Autoantigen in Autoimmune Polyendocrine Syndrome Type I. Biochem. Biophys. Res. Commun. 2000, 267, 456-461. [CrossRef]

78. Alimohammadi, M.; Dubois, N.; Sköldberg, F.; Hallgren, Å.; Tardivel, I.; Hedstrand, H.; Haavik, J.; Husebye, E.S.; Gustafsson, J.; Rorsman, F.; et al. Pulmonary autoimmunity as a feature of autoimmune polyendocrine syndrome type 1 and identification of KCNRG as a bronchial autoantigen. Proc. Natl. Acad. Sci. USA 2009, 106, 4396-4401. [CrossRef]

79. Shum, A.K.; Alimohammadi, M.; Tan, C.L.; Cheng, M.H.; Metzger, T.C.; Law, C.S.; Lwin, W.; Perheentupa, J.; Bour-Jordan, H.; Carel, J.C.; et al. BPIFB1 Is a Lung-Specific Autoantigen Associated with Interstitial Lung Disease. Sci. Transl. Med. 2013, 5 , 206ra139. [CrossRef]

80. Meager, A.; Visvalingam, K.; Peterson, P.; Möll, K.; Murumägi, A.; Krohn, K.; Eskelin, P.; Perheentupa, J.; Husebye, E.; Kadota, Y.; et al. Anti-Interferon Autoantibodies in Autoimmune Polyendocrinopathy Syndrome Type 1. PLoS Med. 2006, 3, e289. [CrossRef] [PubMed]

81. Wolff, A.S.B.; Sarkadi, A.K.; Maródi, L.; Kärner, J.; Orlova, E.; Oftedal, B.E.V.; Kisand, K.; Olah, E.; Meloni, A.; Myhre, A.G.; et al. Anti-Cytokine Autoantibodies Preceding Onset of Autoimmune Polyendocrine Syndrome Type I Features in Early Childhood. J. Clin. Immunol. 2013, 33, 1341-1348. [CrossRef] [PubMed]

82. Barzaghi, F.; Passerini, L. IPEX Syndrome: Improved Knowledge of Immune Pathogenesis Empowers Diagnosis. Front. Pediatr. 2021, 9, 612760. [CrossRef]

83. Rosenberg, J.M.; Maccari, M.E.; Barzaghi, F.; Allenspach, E.J.; Pignata, C.; Weber, G.; Torgerson, T.R.; Utz, P.J.; Bacchetta, R. Neutralizing Anti-Cytokine Autoantibodies Against Interferon- $\alpha$ in Immunodysregulation Polyendocrinopathy Enteropathy X-Linked. Front. Immunol. 2018, 9, 544. [CrossRef] 
84. Bastard, P.; Rosen, L.B.; Zhang, Q.; Michailidis, E.; Hoffmann, H.-H.; Zhang, Y.; Dorgham, K.; Philippot, Q.; Rosain, J.; Béziat, V.; et al. Auto-antibodies against type I IFNs in patients with life-threatening COVID-19. Science 2020, 370, eabd4585. [CrossRef]

85. Beccuti, G.; Ghizzoni, L.; Cambria, V.; Codullo, V.; Sacchi, P.; Lovati, E.; Mongodi, S.; Iotti, G.A.; Mojoli, F. A COVID-19 pneumonia case report of autoimmune polyendocrine syndrome type 1 in Lombardy, Italy: Letter to the editor. J. Endocrinol. Investig. 2020, 43, 1175-1177. [CrossRef]

86. Cavadini, P.; Vermi, W.; Facchetti, F.; Fontana, S.; Nagafuchi, S.; Mazzolari, E.; Sediva, A.; Marrella, V.; Villa, A.; Fischer, A.; et al. AIRE deficiency in thymus of 2 patients with Omenn syndrome. J. Clin. Investig. 2005, 115, 728-732. [CrossRef] [PubMed]

87. Lemarquis, A.; Campbell, T.; Aranda-Guillén, M.; Hennings, V.; Brodin, P.; Kämpe, O.; Blennow, K.; Zetterberg, H.; Wennerås, C.; Eriksson, K.; et al. Severe COVID-19 in an APS1 patient with interferon autoantibodies treated with plasmapheresis. J. Allergy Clin. Immunol. 2021, 148, 96-98. [CrossRef] [PubMed]

88. Meisel, C.; Akbil, B.; Meyer, T.; Lankes, E.; Corman, V.M.; Staudacher, O.; Unterwalder, N.; Kölsch, U.; Drosten, C.; Mall, M.A.; et al. Mild COVID-19 despite autoantibodies against type I IFNs in autoimmune polyendocrine syndrome type 1. J. Clin. Investig. 2021, 131. [CrossRef]

89. Dawoodji, A.; Chen, J.-L.; Shepherd, D.; Dalin, F.; Tarlton, A.; Alimohammadi, M.; Penna-Martinez, M.; Meyer, G.; Mitchell, A.L.; Gan, E.H.; et al. High Frequency of Cytolytic 21-Hydroxylase-Specific CD8+ T Cells in Autoimmune Addison's Disease Patients. J. Immunol. 2014, 193, 2118-2126. [CrossRef]

90. Taniguchi, R.T.; DeVoss, J.J.; Moon, J.J.; Sidney, J.; Sette, A.; Jenkins, M.; Anderson, M.S. Detection of an autoreactive T-cell population within the polyclonal repertoire that undergoes distinct autoimmune regulator (Aire)-mediated selection. Proc. Natl. Acad. Sci. USA 2012, 109, 7847-7852. [CrossRef] [PubMed]

91. Blechschmidt, K.; Schweiger, M.; Wertz, K.; Poulson, R.; Christensen, H.-M.; Rosenthal, A.; Lehrach, H.; Yaspo, M.-L. The Mouse Aire Gene: Comparative Genomic Sequencing, Gene Organization, and Expression. Genome Res. 1999, 9, $158-166$.

92. Wang, C.-Y.; Shi, J.-D.; Davoodi-Semiromi, A.; She, J.-X. Cloning ofAire, the Mouse Homologue of the Autoimmune Regulator (AIRE) Gene Responsible for Autoimmune Polyglandular Syndrome Type 1 (APS1). Genomics 1999, 55, 322-326. [CrossRef] [PubMed]

93. Mathis, D.; Benoist, C. Aire. Annu. Rev. Immunol. 2009, 27, 287-312. [CrossRef] [PubMed]

94. Ramsey, C.; Winqvist, O.; Puhakka, L.; Halonen, M.; Moro, A.; Kämpe, O.; Eskelin, P.; Pelto-Huikko, M.; Peltonen, L. Aire deficient mice develop multiple features of APECED phenotype and show altered immune response. Hum. Mol. Genet. 2002, 11, 397-409. [CrossRef] [PubMed]

95. Hubert, F.-X.; Kinkel, S.A.; Crewther, P.E.; Cannon, P.Z.F.; Webster, K.E.; Link, M.; Uibo, R.; O’Bryan, M.; Meager, A.; Forehan, S.P.; et al. Aire-Deficient C57BL/6 Mice Mimicking the Common Human 13-Base Pair Deletion Mutation Present with Only a Mild Autoimmune Phenotype. J. Immunol. 2009, 182, 3902-3918. [CrossRef] [PubMed]

96. Su, M.; Giang, K.; Žumer, K.; Jiang, H.; Oven, I.; Rinn, J.; Devoss, J.J.; Johannes, K.P.A.; Lu, W.; Gardner, J.; et al. Mechanisms of an autoimmunity syndrome in mice caused by a dominant mutation in Aire. J. Clin. Investig. 2008, 118, 1712-1726. [CrossRef] [PubMed]

97. Goldfarb, Y.; Givony, T.; Kadouri, N.; Dobeš, J.; Peligero-Cruz, C.; Zalayat, I.; Damari, G.; Dassa, B.; Ben-Dor, S.; Gruper, Y.; et al. Mechanistic dissection of dominant AIRE mutations in mouse models reveals AIRE autoregulation. J. Exp. Med. $2021,218$. [CrossRef]

98. Pontynen, N.; Miettinen, A.; Arstila, T.P.; Kämpe, O.; Alimohammadi, M.; Vaarala, O.; Peltonen, L.; Ulmanen, I. Aire deficient mice do not develop the same profile of tissue-specific autoantibodies as APECED patients. J. Autoimmun. 2006, 27, 96-104. [CrossRef]

99. Kojima, A.; Prehn, R.T. Genetic susceptibility to post-thymectomy autoimmune diseases in mice. Immunogenetics 1981, $14,15-27$. [CrossRef]

100. Taguchi, O.; Nishizuka, Y.; Sakakura, T.; Kojima, A. Autoimmune oophoritis in thymectomized mice: Detection of circulating antibodies against oocytes. Clin. Exp. Immunol. 1980, 40, 540-553.

101. Tun, K.S.K.; Setiady, Y.Y.; Samy, E.T.; Lewis, J.; Teuscher, C. Autoimmune Ovarian Disease in Day 3-Thymectomized Mice: The Neonatal Time Window, Antigen Specificity of Disease Suppression, and Genetic Control. Curr. Top. Microbiol. Immunol. 2005, 293, 209-247. [CrossRef]

102. Shum, A.K.; DeVoss, J.; Tan, C.L.; Hou, Y.; Johannes, K.; O'Gorman, C.S.; Jones, K.D.; Sochett, E.B.; Fong, L.; Anderson, M.S. Identification of an Autoantigen Demonstrates a Link Between Interstitial Lung Disease and a Defect in Central Tolerance. Sci. Transl. Med. 2009, 1, 9ra20. [CrossRef] [PubMed]

103. Puel, A.; Döffinger, R.; Natividad, A.; Chrabieh, M.; Morales, G.B.; Picard, C.; Cobat, A.; Ouachée-Chardin, M.; Toulon, A.; Bustamante, J.; et al. Autoantibodies against IL-17A, IL-17F, and IL-22 in patients with chronic mucocutaneous candidiasis and autoimmune polyendocrine syndrome type I. J. Exp. Med. 2010, 207, 291-297. [CrossRef] [PubMed]

104. Kärner, J.; Meager, A.; Laan, M.; Maslovskaja, J.; Pihlap, M.; Remm, A.; Juronen, E.; Wolff, A.S.B.; Husebye, E.S.; Podkrajsek, K.T.; et al. Anti-cytokine autoantibodies suggest pathogenetic links with autoimmune regulator deficiency in humans and mice. Clin. Exp. Immunol. 2013, 171, 263-272. [CrossRef]

105. Lee, D.S.W.; Rojas, O.L.; Gommerman, J.L. B cell depletion therapies in autoimmune disease: Advances and mechanistic insights. Nat. Rev. Drug Discov. 2021, 20, 179-199. [CrossRef] 
106. Ando, T.; Latif, R.; Davies, T. Thyrotropin receptor antibodies: New insights into their actions and clinical relevance. Best Pr. Res. Clin. Endocrinol. Metab. 2005, 19, 33-52. [CrossRef]

107. Smith, B.R.; Sanders, J.; Furmaniak, J. TSH Receptor Antibodies. Thyroid 2007, 17, 923-938. [CrossRef]

108. Howard, F.M.; Lennon, V.A.; Finley, J.; Matsumoto, J.; Elveback, L.R. Clinical Correlations of Antibodies That Bind, Block, or Modulate Human Acetylcholine Receptors in Myasthenia Gravis. Ann. N. Y. Acad. Sci. 1987, 505, 526-538. [CrossRef]

109. Béland, K.; Marceau, G.; Labardy, A.; Bourbonnais, S.; Alvarez, F. Depletion of B cells induces remission of autoimmune hepatitis in mice through reduced antigen presentation and help to T cells. Hepatology 2015, 62, 1511-1523. [CrossRef]

110. O'Neill, S.K.; Shlomchik, M.J.; Glant, T.T.; Cao, Y.; Doodes, P.D.; Finnegan, A. Antigen-Specific B Cells Are Required as APCs and Autoantibody-Producing Cells for Induction of Severe Autoimmune Arthritis. J. Immunol. 2005, 174, 3781-3788. [CrossRef]

111. Wong, F.S.; Wen, L.; Tang, M.; Ramanathan, M.; Visintin, I.; Daugherty, J.; Hannum, L.G.; Janeway, C.A.; Shlomchik, M.J. Investigation of the role of B-cells in type 1 diabetes in the NOD mouse. Diabetes 2004, 53, 2581-2587. [CrossRef] [PubMed]

112. Manca, F.; Fenoglio, D.; Kunkl, A.; Cambiaggi, C.; Sasso, M.; Celada, F. Differential activation of T cell clones stimulated by macrophages exposed to antigen complexed with monoclonal antibodies. A possible influence of paratope specificity on the mode of antigen processing. J. Immunol. 1988, 140, 2893-2898.

113. Amigorena, S.; Bonnerot, C. Role of B-cell and Fc receptors in the selection of T-cell epitopes. Curr. Opin. Immunol. 1998, 10, 88-92. [CrossRef]

114. Watts, C.; Lanzavecchia, A. Suppressive effect of antibody on processing of T cell epitopes. J. Exp. Med. 1993, 178, 1459-1463. [CrossRef]

115. Harris, D.P.; Haynes, L.; Sayles, P.C.; Duso, D.K.; Eaton, S.M.; Lepak, N.M.; Johnson, L.L.; Swain, S.L.; Lund, F.E. Reciprocal regulation of polarized cytokine production by effector B and T cells. Nat. Immunol. 2000, 1, 475-482. [CrossRef] [PubMed]

116. Lund, F.E.; Garvy, B.A.; Randall, T.D.; Harris, D.P. Regulatory Roles for Cytokine- Producing B Cells in Infection and Autoimmune Disease; KARGER: Basel, Switzerland, 2004; Volume 8, pp. 25-54.

117. Aloisi, F.; Borrell, R.P. Lymphoid neogenesis in chronic inflammatory diseases. Nat. Rev. Immunol. 2006, 6, 205-217. [CrossRef]

118. Drayton, D.L.; Liao, S.; Mounzer, R.H.; Ruddle, N.H. Lymphoid organ development: From ontogeny to neogenesis. Nat. Immunol. 2006, 7, 344-353. [CrossRef]

119. Fillatreau, S.; Sweenie, C.H.; McGeachy, M.J.; Gray, D.; Anderton, S.M. B cells regulate autoimmunity by provision of IL-10. Nat. Immunol. 2002, 3, 944-950. [CrossRef]

120. Bouaziz, J.-D.; Yanaba, K.; Tedder, T.F. Regulatory B cells as inhibitors of immune responses and inflammation. Immunol. Rev. 2008, 224, 201-214. [CrossRef]

121. Zhu, Q.; Rui, K.; Wang, S.; Tian, J. Advances of Regulatory B Cells in Autoimmune Diseases. Front. Immunol. 2021, $12,592914$. [CrossRef] [PubMed]

122. Wang, Y.; Qin, Y.; Wang, X.; Zhang, L.; Wang, J.; Xu, X.; Chen, H.; Hsu, H.-T.; Zhang, M. Decrease in the proportion of CD24 hi CD38 hi B cells and impairment of their regulatory capacity in type 1 diabetes patients. Clin. Exp. Immunol. 2019, $200,22-32$. [CrossRef]

123. Hussain, S.; Delovitch, T.L. Intravenous transfusion of BCR-activated B cells protects NOD mice from type 1 diabetes in an IL-10-dependent manner. J. Immunol. 2007, 179, 7225-7232. [CrossRef]

124. Stożek, K.; Grubczak, K.; Marolda, V.; Eljaszewicz, A.; Moniuszko, M.; Bossowski, A. Lower proportion of CD19+IL-10+ and CD19+CD24+CD27+ but not CD1d+CD5+CD19+CD24+CD27+ IL-10+ B cells in children with autoimmune thyroid diseases. Autoimmunity 2019, 53, 46-55. [CrossRef]

125. Peng, B.; Ming, Y.; Yang, C. Regulatory B cells: The cutting edge of immune tolerance in kidney transplantation. Cell Death Dis. 2018, 9, 1-13. [CrossRef]

126. Watanabe, R.; Ishiura, N.; Nakashima, H.; Kuwano, Y.; Okochi, H.; Tamaki, K.; Sato, S.; Tedder, T.F.; Fujimoto, M. Regulatory B Cells (B10 Cells) Have a Suppressive Role in Murine Lupus: CD19 and B10 Cell Deficiency Exacerbates Systemic Autoimmunity. J. Immunol. 2010, 184, 4801-4809. [CrossRef] [PubMed]

127. Evan, J.R.; Bozkurt, S.B.; Thomas, N.C.; Bagnato, F. Alemtuzumab for the treatment of multiple sclerosis. Expert Opin. Biol. Ther. 2018, 18, 323-334. [CrossRef]

128. Ruck, T.; Bittner, S.; Wiendl, H.; Meuth, S.G. Alemtuzumab in Multiple Sclerosis: Mechanism of Action and Beyond. Int. J. Mol. Sci. 2015, 16, 16414-16439. [CrossRef] [PubMed]

129. Agius, M.A.; Klodowska-Duda, G.; Maciejowski, M.; Potemkowski, A.; Eliezer, K.; Patra, K.; Wesley, J.; Madani, S.; Barron, G.; Katz, E.; et al. Safety and tolerability of inebilizumab (MEDI-551), an anti-CD19 monoclonal antibody, in patients with relapsing forms of multiple sclerosis: Results from a phase 1 randomised, placebo-controlled, escalating intravenous and subcutaneous dose study. Mult. Scler. J. 2019, 25, 235-245. [CrossRef] [PubMed]

130. Frampton, J.E. Inebilizumab: First Approval. Drugs 2020, 80, 1259-1264. [CrossRef]

131. Edwards, J.C.; Szczepanski, L.; Szechinski, J.; Filipowicz-Sosnowska, A. Efficacy of B-cell-targeted therapy with rituximab in patients with rheumatoid arthritis. N. Engl. J. Med. 2004, 350, 2572-2581. [CrossRef] [PubMed]

132. He, D.; Guo, R.; Zhang, F.; Zhang, C.; Dong, S.; Zhou, H. Rituximab for relapsing-remitting multiple sclerosis. Cochrane Database Syst. Rev. 2013, 2013, CD009130. [CrossRef]

133. McGinley, M.P.; Moss, B.; Cohen, J.A. Safety of monoclonal antibodies for the treatment of multiple sclerosis. Expert Opin. Drug Saf. 2017, 16, 89-100. [CrossRef] [PubMed] 
134. Teng, Y.K.O.; Bruce, I.N.; Diamond, B.; Furie, R.A.; Van Vollenhoven, R.F.; Gordon, D.; Groark, J.; Henderson, R.B.; Oldham, M.; Tak, P.P. Phase III, multicentre, randomised, double-blind, placebo-controlled, 104-week study of subcutaneous belimumab administered in combination with rituximab in adults with systemic lupus erythematosus (SLE): BLISS-BELIEVE study protocol. BMJ Open 2019, 9, e025687. [CrossRef] [PubMed]

135. Cambridge, G.; Leandro, M.J.; Teodorescu, M.; Manson, J.; Rahman, A.; Isenberg, D.; Edwards, J.C. B cell depletion therapy in systemic lupus erythematosus: Effect on autoantibody and antimicrobial antibody profiles. Arthritis Rheum. 2006, 54, 3612-3622. [CrossRef]

136. Pescovitz, M.D.; Torgerson, T.R.; Ochs, H.D.; Ocheltree, E.; McGee, P.; Krause-Steinrauf, H.; Lachin, J.; Canniff, J.; Greenbaum, C.; Herold, K.C.; et al. Effect of rituximab on human in vivo antibody immune responses. J. Allergy Clin. Immunol. 2011, 128, 1295-1302.e5. [CrossRef] [PubMed]

137. Roberts, D.M.; Jones, R.; Smith, R.M.; Alberici, F.; Kumaratne, D.S.; Burns, S.; Jayne, D.R. Rituximab-associated hypogammaglobulinemia: Incidence, predictors and outcomes in patients with multi-system autoimmune disease. J. Autoimmun. 2015, 57, 60-65. [CrossRef]

138. Eming, D.; Nagel, A.; Wolff-Franke, S.; Podstawa, E. Rituximab Exerts a Dual Effect in Pemphigus Vulgaris. J. Investig. Dermatol. 2008, 128, 2850-2858. [CrossRef] [PubMed]

139. Stasi, R.; Del Poeta, G.; Stipa, E.; Evangelista, M.L.; Trawinska, M.M.; Cooper, N.; Amadori, S. Response to B-cell-depleting therapy with rituximab reverts the abnormalities of T-cell subsets in patients with idiopathic thrombocytopenic purpura. Blood 2007, 110, 2924-2930. [CrossRef] [PubMed]

140. Hoch, W.; McConville, J.; Helms, S.; Newsom-Davis, J.; Melms, A.; Vincent, A. Auto-antibodies to the receptor tyrosine kinase MuSK in patients with myasthenia gravis without acetylcholine receptor antibodies. Nat. Med. 2001, 7, 365-368. [CrossRef]

141. Sangwook, O.; Kevin, O.C.; Aimee, P. MuSK Chimeric Autoantibody Receptor (CAAR) T Cells for Antigen-specific Cellular Immunotherapy of Myasthenia Gravis (2769). Neurology 2020, 94, 2769.

142. Ellebrecht, C.T.; Bhoj, V.G.; Nace, A.; Choi, E.J.; Mao, X.; Cho, M.J.; Di Zenzo, G.; Lanzavecchia, A.; Seykora, J.T.; Cotsarelis, G.; et al. Reengineering chimeric antigen receptor T cells for targeted therapy of autoimmune disease. Science 2016, 353, 179-184. [CrossRef]

143. Bollmann, F.M. Rheumatic autoimmune diseases: Proposed elimination of autoreactive B-cells with magnetic nanoparticle-linked antigens. Med. Hypotheses 2012, 78, 479-481. [CrossRef]

144. Imura, Y.; Ando, M.; Kondo, T.; Ito, M.; Yoshimura, A. CD19-targeted CAR regulatory T cells suppress B cell pathology without GvHD. JCI Insight 2020, 5, e136185. [CrossRef]

145. Townsend, M.; Monroe, J.G.; Chan, A.C. B-cell targeted therapies in human autoimmune diseases: An updated perspective. Immunol. Rev. 2010, 237, 264-283. [CrossRef]

146. Vincent, F.B.; Morand, E.F.; Mackay, F. BAFF and innate immunity: New therapeutic targets for systemic lupus erythematosus. Immunol. Cell Biol. 2012, 90, 293-303. [CrossRef]

147. Musette, P.; Bouaziz, J.D. B Cell Modulation Strategies in Autoimmune Diseases: New Concepts. Front. Immunol. $2018,9,622$. [CrossRef] [PubMed]

148. Jagessar, S.A.; Heijmans, N.; Bauer, J.; Blezer, E.; Laman, J.D.; Migone, T.-S.; Devalaraja, M.N.; Hart, B.A. T Antibodies Against Human BLyS and APRIL Attenuate EAE Development in Marmoset Monkeys. J. Neuroimmune Pharmacol. 2012, 7, 557-570. [CrossRef] [PubMed]

149. Mackay, F.; Schneider, P. Cracking the BAFF code. Nat. Rev. Immunol. 2009, 9, 491-502. [CrossRef] [PubMed]

150. Furie, R.; Rovin, B.H.; Houssiau, F.; Malvar, A.; Teng, Y.O.; Contreras, G.; Amoura, Z.; Yu, X.; Mok, C.-C.; Santiago, M.B.; et al. Two-Year, Randomized, Controlled Trial of Belimumab in Lupus Nephritis. N. Engl. J. Med. 2020, 383, 1117-1128. [CrossRef] [PubMed]

151. Kaegi, C.; Steiner, U.C.; Wuest, B.; Crowley, C.; Boyman, O. Systematic Review of Safety and Efficacy of Atacicept in Treating Immune-Mediated Disorders. Front. Immunol. 2020, 11, 433. [CrossRef]

152. Kalled, S.L.; Cutler, A.H.; Ferrant, J.L. Long-term anti-CD154 dosing in nephritic mice is required to maintain survival and inhibit mediators of renal fibrosis. Lupus 2001, 10, 9-22. [CrossRef]

153. Wang, X.; Huang, W.; Schiffer, L.E.; Mihara, M.; Akkerman, A.; Hiromatsu, K.; Davidson, A. Effects of anti-CD154 treatment on B cells in murine systemic lupus erythematosus. Arthritis Rheum. 2003, 48, 495-506. [CrossRef] [PubMed]

154. Li, Y.; Chen, F.; Putt, M.; Koo, Y.K.; Madaio, M.; Cambier, J.C.; Cohen, P.L.; Eisenberg, R.A. B Cell Depletion with Anti-CD79 mAbs Ameliorates Autoimmune Disease in MRL/lpr Mice1. J. Immunol. 2008, 181, 2961-2972. [CrossRef]

155. Honigberg, L.A.; Smith, A.M.; Sirisawad, M.; Verner, E.; Loury, D.; Chang, B.; Li, S.; Pan, Z.; Thamm, D.; Miller, R.A.; et al. The Bruton tyrosine kinase inhibitor PCI-32765 blocks B-cell activation and is efficacious in models of autoimmune disease and B-cell malignancy. Proc. Natl. Acad. Sci. USA 2010, 107, 13075-13080. [CrossRef] [PubMed]

156. Gatumu, M.; Skarstein, K.; Papandile, A.; Browning, J.L.; Fava, R.A.; Bolstad, A.I. Blockade of lymphotoxin-beta receptor signaling reduces aspects of Sjögren syndrome in salivary glands of non-obese diabetic mice. Arthritis Res. Ther. 2009, 11, R24. [CrossRef] [PubMed] 